\title{
THE LIFESTYLE OF UNIVERSITY STUDENTS: ALCOHOL CONSUMPTION ISSUES
}

\author{
Birutė Strukčinskienė $\dot{1}^{1}$, Neringa Strazdienè ${ }^{2}$, Alona Rauckienė-Michaelsson ${ }^{1}$, \\ Vaiva Strukčinskaitė ${ }^{3}$, Dileta Tervydytè ${ }^{1}$, Emilija Griškonytė ${ }^{4}$, Sigitas Griškonis ${ }^{1,5}$ \\ ${ }^{1}$ Faculty of Health Sciences, Klaipeda University, Lithuania, ${ }^{2}$ Faculty of Social Sciences and \\ Humanities, Klaipeda University, Lithuania, ${ }^{3}$ Faculty of Medicine, Vilnius University, Lithuania, \\ ${ }^{4}$ Faculty of Medicine, Lithuanian University of Health Sciences, Lithuania, \\ ${ }^{5}$ Klaipeda University Hospital, Lithuania
}

Key words: adolescents, young people, students, alcohol consumption, psychoactive substances, prevention.

\begin{abstract}
Summary
Introduction. Alcohol consumption has a negative impact on the health of children, adolescents and young people, including students. Students' alcohol consumption studies could help prevent the use of harmful psychoactive substances.

Materials and Methods. 319 university students participated in the written survey. SPSS (version 24.0) programme has been used for statistical data analysis. The criterion $\chi^{2}$ has been applied and the data was considered to be statistically significant when $\mathrm{p} \leq 0.05$.

Results. The study involved 143 (44.8\%) boys and $176(55.2 \%)$ girls. The majority of students $(90.3 \%)$ have consumed alcohol in the period of the last 12 months. Half of the respondents $(47 \%)$ indicated that they consume beer several times a month. $58 \%$ of the respondents consume wine, and low-alcohol beverages (Cider, Mix, Fizz, alcoholic cocktails) several times a month are consumed by $42 \%$ of students. 55 $\%$ of the respondents do not consume above mentioned low-alcohol beverages at all. Vodka and other strong alcoholic drinks are not consumed by $54 \%$ of the respondents at all, while $43 \%$ of the respondents consume these beverages several times a month. Half of the respondents ( $48 \%$ ) have for several times been under the influence of alcohol after having drunk large amounts of alcohol, and 33\% of the respondents have been under the influence of alcohol more
\end{abstract}

than ten times. Both girls and boys consume vodka and other strong alcoholic beverages equally often. However, girls rather than boys consume wine significantly more often.

Half of the respondents $(50 \%)$ have noted that friends make major impact on the consumption of alcohol by young people, while $22 \%$ of the respondents believe that it is the lack of employment and busyness. In the students' opinion the key role in the prevention of smoking and alcohol drinking lies with parents $(37 \%)$, friends $(27.9 \%)$ and the media $(25.1 \%)$. $75.9 \%$ of the respondents said that they had enough knowledge about a healthy lifestyle, and $19.7 \%$ of the respondents said that they have doubts as regards their knowledge on healthy lifestyle.

Conclusions. Over the last year and during the last month alcohol has been consumed by the majority of students that participated in the survey. Both girls and boys consume alcohol equally often. The key causes of alcohol consumption by students are the influence of friends and the lack of employment and busyness. The study has revealed that most students believe that they have enough knowledge about healthy lifestyles. However, it is recommended to pay more attention to prevention of alcohol consumption by adolescents and young people. Reducing alcohol consumption should be a priority in health policy formulation at local and national levels.

\section{Introduction}

The years of studies are a period of intense learning, high mental and physical capacity, new challenges and experi- 
ences, as well as the development of lifestyle habits and a social environment. Studies at a higher education institution are associated with a change in the living environment and the development of new lifestyle habits [1]. These factors have influence on the consumption of alcohol by students.

In the last decade, the total consumption of alcohol has increased [2]. Alcohol has a negative impact on all systems of the human body: cardiovascular system, musculoskeletal system (bones), mental health, etc. [3-11]. Its consumption has extremely negative consequences on the health and well-being of young people $[2,12]$.

In recent years, great attention has been paid to the prevention of the use of psychoactive substances by schoolchildren, and the preventive measures have been established. Legislation identifies the responsibilities and actions of school authorities in the prevention of the use of psychoactive substances; it also defines the measures to be taken in case of the use of psychoactive substances. There are children's welfare commissions at schools that implement preventive projects against the use of the above-mentioned harmful substances; they submit proposals to school authorities for the appointment of a child's minimum or moderate care [13-15].

Research conducted within the adolescent group has shown that a better understanding of the harmful effects that alcohol poses on the development of adolescents, the implementation of the appropriate preventive measures, changes in social norms and conditions, and the provision of social welfare can have positive effects in reducing alcohol consumption by adolescents [16, 17]. At present little attention is being paid to solving the problem of alcohol consumption by young people in Lithuania. This issue is particularly relevant when we speak about students. Therefore, the analysis of this issue could help to develop, implement and apply preventive measures and programmes aimed at reducing students' alcohol consumption.

The aim of the study was to analyse the situation of alcohol consumption by students at Klaipeda University.

\section{Methodology}

To conduct the research a written survey has been accomplished. 319 Klaipeda University students participated in the survey. The study has used a questionnaire designed with reference to the lifestyle of young people project carried out by the Faculty of Health Sciences at Klaipeda University and Ministry of Education and Science of Lithuania. SPSS (version 24.0) programme has been used for statistical data analysis. The criterion $\chi^{2}$ has been applied to analyse the data. The data was considered to be statistically significant when $p \leq$ 0.05 . The authorization of the Bio-

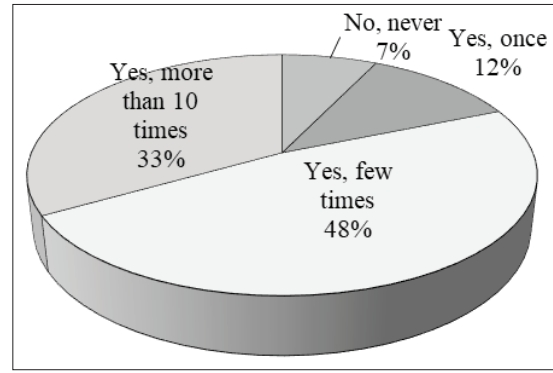

Figure 1. Have you ever consumed such amounts of alcohol beverages, which made you feel drunk?

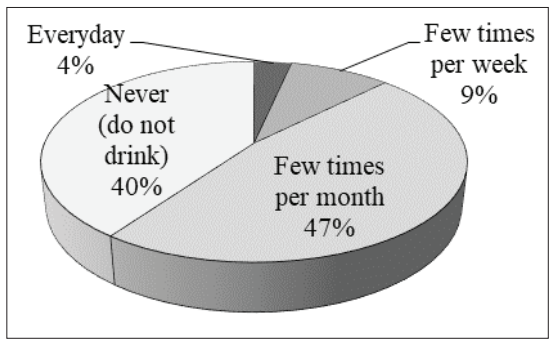

a) Consumption of beer ethics Committee has been obtained to carry out the study.

\section{Results}

319 respondents participated in the survey on student lifestyle and problems of the use of psychoactive substances. The study involved 143 (44.8\%) boys and $176(55.2 \%)$ girls. The survey has revealed that majority of students $(90.3$ $\%$ ) have consumed alcoholic beverages in the period of the last twelve months. When asked if students have consumed any alcohol beverage in the period of the

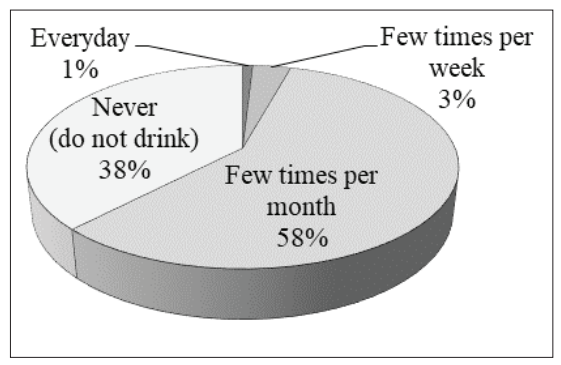

b) Consumption of wine

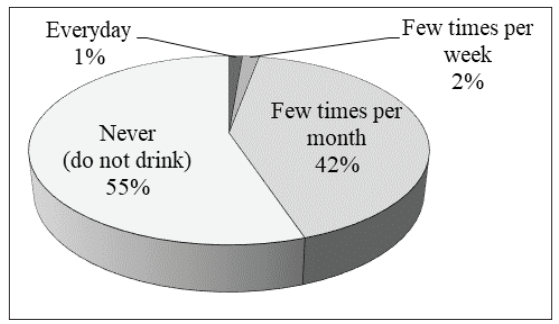

c) Consumption of low-alcohol beverages, such as Cider, Mix, Fizz, alcoholic cocktails

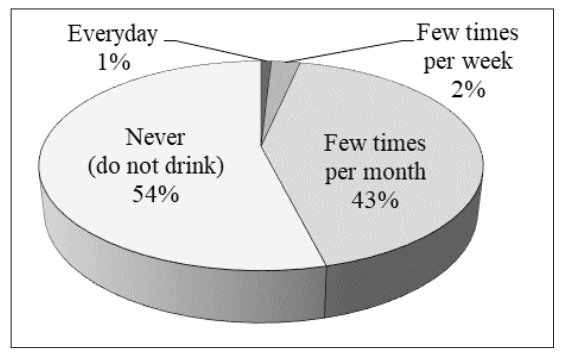

d) Consumption of vodka and strong alcoholic drinks

Figure 2. Consumption of various alcoholic drinks: a), b), c), d). 
last 30 days, $80 \%$ of the respondents said "yes". The survey has disclosed that nearly half of the respondents (48\%) have drunk large amounts of alcohol for several times, and $33 \%$ of the respondents have consumed large amounts of alcohol more than ten times (Figure 1).

Nearly half of the respondents (47\%) said that they drink beer several times a month. 58\% of the respondents' drink wine several times a month. Low-alcohol beverages (Cider, Mix, Fizz, alcoholic cocktails) are consumed several times a month by $42 \%$ of students. $55 \%$ of the respondents do not consume the above mentioned low-alcohol beverages at all. $54 \%$ of the students do not consume vodka and other strong alcohol beverages at all, and $43 \%$ of the respondents consume these alcohol beverages several times a month (Figure 2 ). Both girls and boys consume strong alcohol beverages and beer equally often ( $>0.5)$. Girls consume wine significantly more often $(\mathrm{p}<0.05)$ than boys.

Half of the respondents believe that their friends play the key role in consumption of alcoholic drinks by young people. $22 \%$ of the respondents indicate that it is the lack of employment and busyness that makes young people to consume alcoholic drinks.

The study has revealed that in students' opinion $92 \%$ of young people have enough knowledge about the harm produced by consumption of alcoholic drinks. $75.9 \%$ of the respondents indicated that they had enough knowledge about a healthy lifestyle in general, and $19.7 \%$ of the respondents

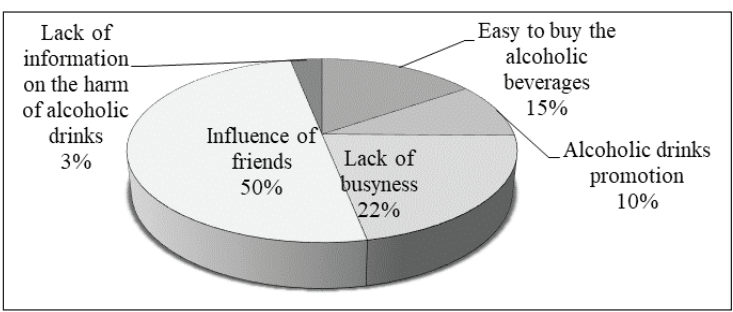

Figure 3. What plays the key role in the consumption of alcoholic drinks by young people?

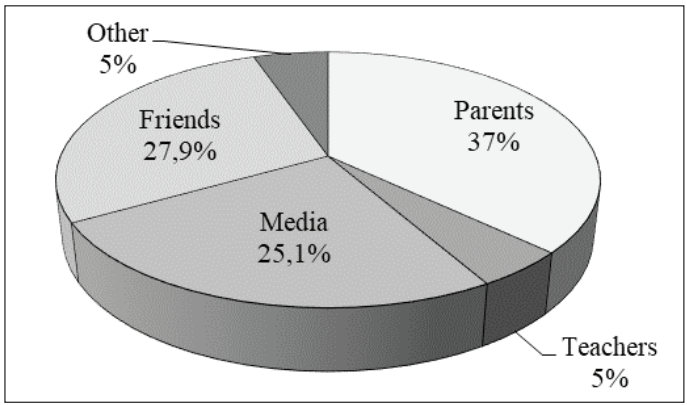

Figure 4. Who plays the key role in prevention of alcohol consumption? said that they have doubts whether their knowledge on this issue is sufficient and correct.

The study has revealed that parents $(37 \%)$, friends $(27.9 \%)$ and the media $(25.1 \%)$ play the key role in the prevention of alcohol consumption by young people (Figure 4).

\section{Discussion}

In Lithuania, the supply of different out-of-school activities for schoolchildren is versatile: schoolchildren can attend different non-formal education clubs, and various programmes for schoolchildren are being implemented. However, insufficient attention is paid to the productive, health-enhancing leisure activities for high school or university students. An important measure for prevention of students' alcohol consumption is the increase of the supply of their free-time activities: establishing conditions for promotion of different sports activities, volunteering opportunities, self-realization activities, or activities related to future professional work. In this context, the promotion of physical activity of students is of primary importance as it is of great significance because it enhances human health and reduces health risk factors [18]. Various physical activities (physical exercises, morning exercise, sports activities, sports games, jogging, swimming, dancing, aerobics, yoga, etc.) are recommended for the prevention of alcohol consumption [19].

Researchers who investigated students' alcohol consumption stated that the key attention in the prevention of alcohol consumption should be focused on formation of expectations [19]. It can be expected that the development of the negative alcohol consumption and consequence expectations in young people could stimulate them to consume alcohol beverages less frequently and in smaller amounts. Therefore, the study programmes at higher educational institution should offer for students more various selective study subjects that focus on health education, health promotion, psychology, etc.; that could help students to obtain knowledge, and to develop positive attitudes and approaches on healthy lifestyle.

Good conditions for the implementation of a short-term intervention in schools have been established in Lithuania, as schools adjust a well-developed practice of cooperation among different specialists [20]. However, higher education institutions in Lithuania do not sufficiently apply the positive possibilities of a short-term intervention. Systemic studies conducted by US researchers have proved that the effectiveness of a short-term intervention can be affected by the location where it is provided. It was identified that results that are more effective were obtained in trials where a short-term intervention was provided at teaching/academic institutions compared to short-term intervention provided at community institutions [21]. Interventions at an individual 
level, the measures of alcohol control policy, and reduction of the accessibility to alcoholic beverages could reduce the consumption of alcohol by students and young people.

\section{Conclusions}

The majority of the respondents that participated in the survey have consumed alcoholic drinks in the period of the last twelve months and during the last month. Both girls and boys consume alcohol equally often. Girls rather than boys prefer wine to other alcohol drinks. The key causes of alcohol consumption by students are the influence of their friends and the lack of employment and busyness. The study has revealed that most students believe that they have enough knowledge about healthy lifestyles. However, it is recommended to pay more attention to prevention of alcohol consumption by adolescents and young people. Reducing alcohol consumption should be a priority in health policy formulation both at local and national levels.

\section{References}

1. Dobrovolskij V., Stukas R. The peculiarities of use of psychoactive substances among students in Lithuania high schools. Health Sciences 2014; 24(3): 16-22.

https://doi.org/10.5200/sm-hs.2014.037

2. Stelemekas M. Social and economic harm of alcohol in Lithuania. Doctoral dissertation. Kaunas. LSMU, 2014.

3. Fernández-Solà J. Cardiovascular risks and benefits of moderate and heavy alcohol consumption. Nature 2015;12(10): 576-587.

4. De Gaetano G, Costanzo S, Di Castelnuovo A, Badimon L, D, A, Chiva-Blanch G, R, C, Panico ., Pounis G, Sofi F, Stranges S, Trevisan M, Ursini F, Cerletti C, Donati MB, Iacoviello L. Effects of moderate beer consumption on health and disease: a consensus document. Nutrition, Metabolism and Cardiovascular Diseases 2016; 26(6):443-467.

https://doi.org/10.1016/j.numecd.2016.03.007

5. Chiva-Blanch G, Arranz S, Lamuela-Raventos RM, Estruch R. Effects of wine, alcohol and polyphenols on cardiovascular disease risk factors: evidences from human studies. Alcohol and Alcoholism 2013; 48(3):270-277

https://doi.org/10.1093/alcalc/agt007

6. Chiva-Blanch G, Magraner E, Condines X, Valderas-Martínez P, Roth I, Arranz S, Casas R, Navarro M, Hervas A, Sisó A, Martínez-Huélamo M, Vallverdú-Queralt A, Quifer-Rada P, Lamuela-Raventos RM, Estruch R. Effects of alcohol and polyphenols from beer on atherosclerotic biomarkers in high cardiovascular risk men: a randomized feeding trial. Nutrition, Metabolism and Cardiovascular Diseases 2015; 25(1): 36-45. https://doi.org/10.1016/j.numecd.2014.07.008

7. O`Keefe JH, Bhatti SK, Bajwa A, DiNicolantonio JJ, Lavie CJ. Alcohol and cardiovascular health: the dose makes the poison... or the remedy. Mayo Clinic Proceedings 2014; 89(3):382-393. https://doi.org/10.1016/j.mayocp.2013.11.005

8. Kubo JT, Henderson MT, Desai M, Wactawski-Wende J, Stefanick ML, Tang JY. Alcohol consumption and risk of melanoma and non-melanoma skin cancer in the Women's Health Initiative. Cancer Causes \& Control 2014; 25(1):1-10.

https://doi.org/10.1007/s10552-013-0280-3

9. Seo S, Chun S, Newell MA, Yun M. Association between alcohol consumption and Korean young women's bone health: a cross sectional study from the 2008 to 2011 Korea national health and nutrition examination survey. BMJ Open 2015; 5(10): 1-10. https://doi.org/10.1136/bmjopen-2015-007914

10. Bell S, Britton A. An exploration of the dynamic longitudinal relationship between mental health and alcohol consumption: a prospective cohort study. BMC Medicine 2014; 12: 91. https://doi.org/10.1186/1741-7015-12-91

11.Wang KS, Liu X, Wang L. Associations of alcohol consumption and mental health with the prevalence of arthritis among US adults: data from the 2012 national health interview survey. Rheumatology International 2014; 34(9):1241-1249. https://doi.org/10.1007/s00296-014-2992-4

12. Young people and alcohol: a Resource book. Geneva: World Health Organization 2015.

13. Stoniene L, Izokaitis M. School educators approach to accessibility to early psychoactive substances abuse interventions for students in general education schools. Public Health 2017; 3(78): 81-90.

14. Lietuvos Respublikos švietimo ir mokslo ministro $2006 \mathrm{~m}$. kovo 17 d. ịsakymas Nr. 494 „Dèl alkoholio, tabako ir kitų psichiką veikiančių medžiagų vartojimo prevencijos programos patvirtinimo". Valstybès žinios, 2006.

15. Jurgaitiene D, Strukcinskiene B, Sopagiene D. Klaipeda city schoolchildren's self-reported attitude to alcohol consumption and prevention possibilities at school. Public Health 2015; annex Nr. 1: 30-35.

16. Looze MD, Raaijmakers Q, Bogt TT. Bendtsen P, Farhat T, Ferreira M. et al. Decreases in adolescent weekly alcohol use in Europe and North America: evidence from 28 countries from 2002 to 2010. European Journal of Public Health 2015; 25 (2): 69-72.

https://doi.org/10.1093/eurpub/ckv031

17. Bräker AB, Soellner R. Alcohol drinking cultures of European adolescents. European Journal of Public Health 2016; 26(4): 581-586.

https://doi.org/10.1093/eurpub/ckw033

18. Adaskeviciene E, Strazdiene N. Education of pupils‘ physical activity. Klaipeda. KU leidykla, 2017.

19. Strukcinskiene B, Raistenskis J, Radziuviene R, Strukcinskaite V. Healthy lifestyle in children and teenagers: focus on physical activity. Klaipeda. Druka, 2018.

20. Bulotaite L., Baltrusaityte R. Alcohol expectancies of university students. Public Health 2010; 1(48): 83-89.

21. Trumposios intervencijos: alkoholio vartojimo ịpročių patikros 
ir pagalbos teikimo rekomendacijos. Metodinès rekomendacijos. Vilnius. Higienos institutas, 2016.

\section{UNIVERSITETO STUDENTŲ GYVENSENA: ALKOHOLIO VARTOJIMO ASPEKTAI}

B.Strukčinskienė, N.Strazdienė, A.Rauckienė-Michaelsson, V.Strukčinskaitė, D.Tervydytė, E.Griškonytė, S.Griškonis

Raktažodžiai: paaugliai, jaunimas, studentai, alkoholio vartojimas, psichoaktyviosios medžiagos, prevencija.

Santrauka

Itvadas. Alkoholio vartojimas daro neigiamą poveikį vaikų, paauglių, jaunų žmonių, taip pat ir studentų sveikatai. Studentų alkoholio vartojimo ypatumų tyrimai galètų padèti vykdyti žalingų psichoaktyviujų medžiagų vartojimo prevenciją.

Metodika. Apklausoje raštu dalyvavo 319 Klaipėdos universiteto studentų. Statistinei duomenų analizei naudota SPSS (24.0 versija) programa. Taikytas $\chi^{2}$ kriterijus, duomenys statistiškai reikšmingi, kai $\mathrm{p} \leq 0,05$.

Rezultatai. Tyrime dalyvavo 143 (44,8 proc.) vaikinai ir 176 (55,2 proc.) merginos. Pastarujų 12 mènesių laikotarpiu alkoholi vartojo dauguma (90,3 proc.) studentų. Pusė respondentų alų geria kelis kartus per mėnesị (47 proc.). Kelis kartus per mėnesį vyną geria 58 proc. respondentų, o silpnus alkoholinius gèrimus (sidrą, Mix, Fizz, alkoholinius kokteilius) - 42 proc. studentų. 55 proc. respondentų minètų silpnų alkoholinių gèrimų nevartoja. Degtinès ir kitų stipriujų gėrimų nevartoja 54 proc. respondentų, o kelis kartus per mènesį išgeria 43 proc. respondentų. Nuo didelio kiekio išgerto alkoholio keletą kartų apsvaigę buvo pusė (48 proc.) apklaustųjų, o daugiau nei 10 kartų apsvaigę buvo 33 proc. respondentų. Degtinę ir kitus stipriuosius gèrimus bei alų merginos ir vaikinai vartoja vienodai dažnai. Vyną reikšmingai dažniau vartoja merginos.

Pusè (50 proc.) respondentų mano, kad pagrindinę įtaką jaunimo alkoholio vartojimui daro draugai, o 22 proc.- užimtumo stoka. Pagrindinis vaidmuo rūkymo ir alkoholio prevencijai, studentų nuomone, tenka tėvams (37 proc.), draugams (27,9 proc.) ir žiniasklaidai ( 25,1 proc.). 75,9 proc. respondentų atsakè, kad turi pakankamai žinių apie sveiką gyvenseną, o savo žiniomis abejoja 19,7 proc. apklaustujų̧.

Išvados. Pastarųų metų laikotarpiu ir pastarojo mėnesio laikotarpiu alkoholį vartojo dauguma tirtų studentų. Merginos ir vaikinai beveik visus alkoholinius gėrimus vartoja vienodai dažnai. Pagrindinès studentų alkoholio vartojimo priežastys yra draugų ịtaka ir tinkamo užimtumo stoka. Nors tyrimas atskleidè, kad dauguma studentų mano, kad jie turi pakankamai žinių apie sveiką gyvenseną, visgi rekomenduotina paauglių ir jaunimo alkoholio vartojimo prevencijai skirti daugiau dèmesio. Alkoholio vartojimo mažinimas turètų būti prioritetinis uždavinys formuojant sveikatos politiką vietiniu ir nacionaliniu lygmenimis.

Adresas susirašinèti: birutedoctor@hotmail.com

Gauta 2018-11-26 